Available online at http://journal.stkip-andi-matappa.ac.id/index.php/histogram/index

Histogram : Jurnal Pendidikan Matematika 4(1), 2020, 128 - 138

\title{
ANALISIS KEMAMPUAN LITERASI MATEMATIKA SISWA PADA KONTEN SPACE AND SHAPE
}

\author{
Anis Munfarikhatin ${ }^{1}$, Irmawaty Natsir ${ }^{2}$ \\ $1^{*, 2}$ Universitas Musamus Merauke \\ * Corresponding Author. Email: munfarikhatin_fkip@unmus.ac.id \\ Received: 08 Maret 2020; Revised: 24 Maret 2020; Accepted: 30 Maret 2020
}

\begin{abstract}
ABSTRAK
Kemampuan literasi matematika masih menjadi tren di dunia pendidikan saat ini. PISA merupakan salah satu studi yang mengukur kemampuan siswa dalam proses penalaran, memberikan argumen dan pemecahan masalah. Dari beberapa konten yang diukur, peneliti memfokuskan pada space and shape materi pythagoras. Pertanyaan pada penelitian ini adalah bagiamana kemampuan literasi siswa pada konten space and shape materi pythagoras. Pada penelitian ini, peneliti menggunakan pendekatan kualitatif dengan metode observasi, dokumentasi dan wawancara. Hasil penelitian menunjukkan sebanyak $80 \%$ siswa berada pada level di bawah 1 dan 20\% berada pada level 1. Dari beberapa indikator yang dinilai pada aspek communication menunjukkan skor rata- rata 3,13; skor komponen mathematising rata- rata 2,13; skor komponen representation rata- rata 2,33; skor komponen reasoning and argument ratarata 2,13; skor devising strategies and solving problem 2,56; komponen using symbolic, formal and technical language and operation memperoleh skor rata- rata 3,00; dan skor rata- rata kemampuan using mathematics tools memperoleh skor 2,66. Hasil penelitian menunjukkan bahwa kemampuan literasi siswa pada konten space shape masih sangat rendah.
\end{abstract}

Kata Kunci: literasi matematika; PISA, kualitatif

\begin{abstract}
Mathematical literacy is still a trend in the world of education today. PISA is one study that measures the ability of students in the process of reasoning, providing arguments and problem solving. From some of the content measured, researchers focus on the space and shape of pythagorean material. The question in this study is how the literacy ability of students in the content space and shape pythagorean material. In this study, researchers used a qualitative approach with methods of observation, documentation and interviews. The results showed as many as $80 \%$ of students were at the level below 1 and $20 \%$ were at level 1 . Of the several indicators assessed on the communication aspect showed an average score of 3.13; the average score of the mathematising component is 2.13; average component score score of 2.33; the reasoning and argument component score averaged 2.13; score devising strategies and solving problems 2.56; components using symbolic, formal and technical language and operation obtain an average score of 3.00; and the average score of ability to use mathematics tools obtain a score of 2.66. The results showed that the literacy ability of students in space shape content was still very low.
\end{abstract}

Keywords: mathematics literacy, PISA, kualitatif

How to Cite: Munfarikhatin, A \& Natsir, D. (2020). Analisis Kemampuan Literasi Matematika Siswa pada Konten Space and Shape. Histogram: Jurnal Pendidikan Matematika, 4(1), 128 - 138 , doi: http://dx.doi.org/10.31100/histogram.v4i1.569

Permalink/DOI: http://dx.doi.org/10.31100/histogram.v4i1.569

\section{PENDAHULUAN}

Kegiatan pembelajaran pada kurikulum 2013 menuntut siswa memiliki kemampuan lebih dalam aspek berpikir diantaranya adalah mampu berpikir kritis, mampu

Copyright $@$ 2020, THE AUTHOR (S). This article distributed under the CC-BY-SA-license.

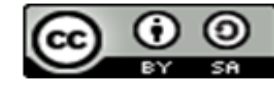




\section{Histogram: Jurnal Pendidikan Matematika, 4 (1), 2020 - 129 Anis Munfarikhatin ${ }^{1 *}$, Irmawaty Natsir ${ }^{2}$}

menghubungkan permasalahan yang diberikan dengan dunia nyata, serta mampu menggunakan teknologi komunikasi dan informasi yang terbaru (Afriyanti, Sri, \& Asih, 2018). Sesuai dengan pembelajaran matematika yang berorientasi pada kemampuan literasi bahwa pengajar dituntut untuk dapat mengolah dengan baik bakat siswa dalam hal kemampuan berpikir, menggabungkan kemampuan sains dan teknologi, terus menerus memperbaiki proses pembelajaran, meningkatakan metode pengajaran dan berinovasi ( Xiaonan, 2018). Pembelajaran matematika merupakan suatu proses memperoleh pengetahuan tentang matematika yang tidak hanya berlangsung di sekola tetapi juga di rumah (Saragih, Palobo, \& Sianturi, 2019).

Pada penilaian lingkup internasional kemampuan matematika siswa di Indonesia dinilai sangat kurang. Berdasarkan hasil survey PISA (Programme for International Student Assessment) yang merupakan studi di bawah lembaga OECD (Organisation for Economic Cooperation and Development) memulai surveynya pada tahun 2000. PISA yang pertama kalinya mengadakan survey yang menilai tentang kesiapan para siswa pada kehidupan dewasa, yang diikuti oleh 41 negara bekerjasama dengan pemerintah negara bersangkutan.

Hasilnya, Indonesia ada pada urutan ke-39 dengan skor 367. Pada Tahun 2003 menempati ranking ke-38 dari 40 negara dengan skor 360. Tahun 2006 yang diikuti oleh 57 negara, Indonesia menempati urutan ke-50. Hasil PISA tahun 2009 posisi Indonesia kembali terpuruk yang hanya menempati posisi ke-61 dari 65 negara partisipan, sedangkan, hasil PISA terbaru pada tahun 2012 Indonesia semakin terpuruk yaitu menduduki peringkat ke-64 dari 65 negara dengan skor rata-rata 375 dari rata-rata skor internasional 494 (OECD, 2013). Dari beberapa hasil survey tersebut posisi Indonesia pada level internasional tidak menunjukkan peningkatan yang signifikan, namun cenderung mengalami kemerosotan. Tidak diragukan lagi bahwa rata-rata kemampuan matematika siswa Indonesia sangatlah rendah.

PISA mencakup tiga domain yaitu (1) komponen konten dalam PISA dimaknai sebagai isi atau materi atau subjek materi yang dipelajari di sekolah, (2) komponen proses dalam studi PISA dimaknai sebagai hal-hal atau langkah-langkah seseorang untuk menyelesaikan suatu permasalahan dalam situasi tertentu dengan menggunakan matematika sebagai alat sehingga permasalahan itu dapat diselesaikan, (3) komponen konteks dalam studi PISA dimaknai sebagai situasi tergambar dalam suatu permasalahan (OECD, 2010). Berikut ini adalah konten matematika yang digunakan dalam PISA matematika sesuai kurikulum sekolah (Hayat, 2010) adalah : Ruang dan bentuk (Space and Shape) berkaitan dengan pokok pelajaran geometri. Soal tentang ruang dan bentuk ini 


\section{Histogram: Jurnal Pendidikan Matematika, 4 (1), 2020 - 130 Anis Munfarikhatin ${ }^{1 *}$, Irmawaty Natsir ${ }^{2}$}

menguji kemampuan siswa mengenali bentuk, mencari persamaan dan perbedaan dalam berbagai dimensi dan representasi bentuk, serta mengenali ciri-ciri suatu benda dalam hubungannya dengan posisi benda tersebut, perubahan dan hubungan (Change and relationship) berkaitan dengan pokok pelajaran aljabar. Hubungan matematika sering dinyatakan dengan persamaan atau hubungan yang bersifat umum . Seperti penambahan, pengurangan, dan pembagian. Hubungan itu juga dinyatakan dalam berbagai simbol aljabar, grafik, bentuk geometris, dan tabel. Oleh karena setiap representasi simbol itu memiliki tujuan dan sifatnya masing-masing, proses penerjemahannya sering menjadi sangat penting dan menentukan sesuai dengan situasi dengan situasi dan tugas yang harus dikerjakan, bilangan (Quantity) berkaitan dengan hubungan bilangan dan pola bilangan, antara lain kemampuan untuk memahami ukuran,pola bilangan, dan segala sesuatu yang berhubungan dengan bilangan dalam kehidupan sehari- hari, seperti menghitung dan mengukur benda tertentu. Termasuk dalam konten bilangan ini adalah kemampuan bernalar secara kuantitatif, mempresentasikan sesuatu dalam angka, memahami langkah-langkah matematika, berhitung di luar kepala, dan melakukan penaksiran, probabilitas/ketidakpastian (Uncertainly) berhubungan dengan statistika dan peluang yang sering digunakan dalam masyarakat. Konsep dan aktivitas matematika yang penting pada bagian ini adalah mengumpulkan data, analisis data dan menyajikan data, peluang dan inferensi.

Salah satu konten yang diukur dalam PISA adalah Space and Shape yang mencakup berbagai fenomena yang ditemui dimana- mana di dalam dunia visual dan fisik kita misalnya: pola, sifat objek, posisi dan orientasi, representasi dari objek, pengkodean informasi visual, navigasi dan interaksi yang dinamis dengan bentuk nyata (OECD, 2013). Geometri merupakan salah satu cabang matematika yang penting, karena geometri bertujuan memfasilitasi siswa untuk berpikir kritis dalam pemecahan masalah (Aydogdu, 2014). Menurut (Adolphus, 2011) Geometri adalah sebuah aspek dari matematika yang mempelajari berbagai bentuk yang berbeda, namun beberapa siswa tidak mampu menerapkan aplikasi matematika khususnya geometri dalam kehidupan keseharian mereka, bahkan mereka tidak mampu memecahkan masalah yang hampir sama dalam kehidupan sehari-hari. Wardani dalam (Setiawan\& Dafik, 2014) mengemukakan soal- soal PISA pada konten space and shape sangat menuntut kemampuan penalaran dan pemecahan masalah.

OECD menjabarkan tingkatan kemampuan literasi matematika dalam studi PISA, khususnya dalam kemampuan matematikannya. Tingkat kemampuan matematika PISA dijabarkan menjadi 7 (tujuh) level, yaitu level 6, level 5, level 4, level 3, level 2, level 1, 


\section{Histogram: Jurnal Pendidikan Matematika, 4 (1), 2020 - 131 \\ Anis Munfarikhatin ${ }^{1 *}$, Irmawaty Natsir ${ }^{2}$}

dan di bawah 1 dalam (Haahr et al, 2005). Tingkatan kemampuan literasi matematika ada 7 (tujuh) tahap yaitu: communication, mathematishing, representation, reasoning and argument, devising strategies for solving problems, using symbolic, formal and technical language and operation, dan using mathematics tools. Karakteristik soal- soal PISA yang terintegrasi dengan aspek yang ada dalam kehidupan sehari- hari dan membangun kemampuan realistis dan berpikir kritis siswa sesuai implementasi pembelajaran matematika kurikulum 2013.

Kemampuan literasi siswa pada konten space and shape. Tujuan penelitian ini adalah untuk mendeskripsikan kemampuan literasi siswa pada konten space and shape. Manfaat dari penelitian ini diantaranya : (1) membiasakan siswa dalam menyelesaikan persoalan matematika yang berorientasi pada pemecahan masalah pada khususnya kemampuan literasi, (2) Guru dapat mengukur sejauh mana kemampuan literasi yang dimiliki siswanya sehingga selanjutnya dapat digunakan sebagai acuan dalam membuat perangkat pembelajaran yang akan digunakan.

Penelitian ini didasari oleh penelitian- penelitian sebelumnya diantaranya : (1) penelitian tentang dampak penilaian PISA terhadap pendidikan matematika pada tahun 2004; (2) penelitian tentang pendidikan karakter untuk meningkatkan kemampuan literasi pada tahun 2015.

\section{METODE PENELITIAN}

Penelitian ini menggunakan pendekatan kualitatif dengan pertimbangan diantaranya : (1) penelitian ini merupakan upaya dalam menganalisis kemampuan literasi matematika pada konten space and shape, (2) penelitian ini merupakan penelitian yang berpijak pada pengamatan langsung dari fakta yang diperoleh (penelitian induktif) sehingga terbuka untuk penelitian yang lebih lanjut, (3) Keadaan psikologis subyek penelitian berada pada keadaan yang wajar dan tidak ada tekanan ataupun paksaan. Rancangan alur penelitian dumulai dengan analisis nilai ulangan harian, kegiatan pembelajaran di kelas, Observasi dan wawancara untuk pengumpulan data awal, menentukan kesimpulan awal, penyusunan soal tes literasi matematika konten space and shape, dokumentasi dan wawancara berdasarkan hasil tes tersebut, penarikan kesimpulan.

Penelitian ini dilaksanakan di Sekolah Menengah Pertama Negeri 1 Winong, yang beralamat di Jalan Winong- Gabus Km. 0,5 Kecamatan Winong Kabupaten Pati, Jawa Tengah. Subyek penelitian ini adalah siswa kelas VIII semester II pada materi pythagoras. Penelitian ini mengamati dan mengukur hasil belajar siswa pada pembelajaran geometri pada konten space and shape yang mengacu pada indikator proses kemampuan literasi 


\section{Histogram: Jurnal Pendidikan Matematika, 4 (1), 2020 - 132 \\ Anis Munfarikhatin 1*, Irmawaty Natsir ${ }^{2}$}

yaitu: (1) communication, (2) mathematising, (3) representation, (4) reasoning and argument, (5) devising strategies for solving problem, (6) using symbolic, formal and technical language and operation, (7) using mathematics tools (OECD, 2018)

Hal yang paling penting dalam penelitian ini adalah pengumpulan data dengan metode wawancara, observasi, wawancara struktur dan tidak terstruktur serta dokumentasi. Teknik triangulasi pada penelitian juga digunakan untuk menghindari bias dari data yang telah diperoleh. Dalam hal ini peneliti menggunakan informan yang berbeda untuk memperkuat keabsahan data. Instrumen penelitian diuji validitas untuk diperoleh instrumen yang valid yang telah divalidasi oleh validator ahli. Uji reliabilitas juga digunakan untuk memperoleh instrumen yang reliabel.

\section{HASIL DAN PEMBAHASAN}

\section{A. Hasil Penelitian.}

Uji validitas dari instrumen wawancara dan soal tes kemampuan literasi matematika memberikan hasil yang valid dengan nilai rata-rata 3,6. Hasil uji reliabilitas menghasilkan instrumen kategori reliabel dengan mengujicobakan pada subjek uji coba. Berdasarkan hasil perhitungan reliabilitas tes diperoleh $r_{11}=0,493$, sedangkan $r_{\text {tabel }}$ pada taraf signifikan $5 \%$ dan $\mathrm{N}=29$ diperoleh $\mathrm{r}_{\text {tabel }}=0,367$. Karena $\mathrm{r}_{11}>\mathrm{r}_{\text {tabel }}$ maka soal tes uji coba reliabel.

Tabel 1. Rekapitulasi skor kemampuan literasi

\begin{tabular}{|c|c|c|c|c|c|c|}
\hline \multirow{2}{*}{ No } & \multirow{2}{*}{ Siswa } & \multicolumn{3}{|c|}{ Skor per butir soal } & \multirow{2}{*}{$\begin{array}{c}\text { Jumlah } \\
\text { skor }\end{array}$} & \multirow{2}{*}{$\begin{array}{c}\text { Skor } \\
\text { Literasi }\end{array}$} \\
\hline & & $\mathbf{1}$ & 2 & 3 & & \\
\hline 1 & S-01 & 20 & 10 & 17 & 47 & 314,86 \\
\hline 2 & S-02 & 22 & 16 & 20 & 58 & 388,63 \\
\hline 3 & S-03 & 10 & 5 & 25 & 40 & 268,11 \\
\hline 4 & S-04 & 18 & 20 & 14 & 52 & 348,35 \\
\hline 5 & S-05 & 20 & 13 & 18 & 51 & 341,68 \\
\hline 6 & S-06 & 16 & 20 & 8 & 44 & 294,80 \\
\hline 7 & S-07 & 10 & 24 & 13 & 47 & 314,87 \\
\hline 8 & S-08 & 15 & 20 & 15 & 50 & 301,65 \\
\hline 9 & S-09 & 10 & 20 & 15 & 45 & 301,56 \\
\hline 10 & S-10 & 14 & 20 & 23 & 57 & 381,86 \\
\hline 11 & S-11 & 8 & 10 & 17 & 35 & 234,54 \\
\hline 12 & S-12 & 12 & 10 & 24 & 46 & 308,01 \\
\hline
\end{tabular}


Histogram: Jurnal Pendidikan Matematika, 4 (1), 2020 - 133 Anis Munfarikhatin ${ }^{1 *}$, Irmawaty Natsir ${ }^{2}$

\begin{tabular}{|c|c|c|c|c|c|c|}
\hline \multirow{2}{*}{ No } & \multirow{2}{*}{ Siswa } & \multicolumn{3}{|c|}{ Skor per butir soal } & \multirow{2}{*}{$\begin{array}{c}\text { Jumlah } \\
\text { skor }\end{array}$} & \multirow{2}{*}{$\begin{array}{c}\text { Skor } \\
\text { Literasi }\end{array}$} \\
\hline & & 1 & 2 & 3 & & \\
\hline 13 & S-13 & 10 & 25 & 15 & 50 & 335,00 \\
\hline 14 & S-14 & 20 & 25 & 15 & 60 & 402,43 \\
\hline 15 & S-15 & 20 & 8 & 14 & 42 & 281,44 \\
\hline 16 & S-16 & 12 & 18 & 6 & 36 & 241,16 \\
\hline 17 & S-17 & 18 & 16 & 15 & 49 & 328,24 \\
\hline 18 & S-18 & 10 & 10 & 15 & 35 & 234,66 \\
\hline 19 & S-19 & 14 & 22 & 20 & 56 & 375,18 \\
\hline 20 & S-20 & 10 & 10 & 15 & 35 & 234,46 \\
\hline 21 & S-21 & 16 & 18 & 15 & 49 & 328,47 \\
\hline 22 & S-22 & 15 & 20 & 10 & 45 & 301,26 \\
\hline 23 & S-23 & 10 & 24 & 9 & 43 & 288,06 \\
\hline 24 & S-24 & 16 & 14 & 10 & 40 & 268,76 \\
\hline 25 & S-25 & 12 & 19 & 20 & 51 & 341,66 \\
\hline 26 & S-26 & 10 & 20 & 15 & 45 & 301,54 \\
\hline 27 & S-27 & 20 & 23 & 20 & 63 & 422,06 \\
\hline 28 & S-28 & 20 & 20 & 25 & 65 & 435,47 \\
\hline 29 & S-29 & 15 & 25 & 13 & 53 & 355,08 \\
\hline 30 & S-30 & 25 & 10 & 15 & 50 & 335,05 \\
\hline Rata & Rata & 14,93 & 17,16 & 15,86 & 47,96 & 320,16 \\
\hline
\end{tabular}

(Sumber: Data Primer, Tahun : 2019)

Hasil tes kemampuan literasi matematika siswa konten space and shape pada materi pythagoras ditunjukkan pada tabel 1. Skor maksimal yang diperoleh siswa adalah 435,5 dan skor mininum adalah 234,5. Ini menunjukkan bahwa sebanyak $80 \%$ siswa berada di bawah level 1 yang artinya siswa tersebut belum mampu menggunakan operasi matematika, mereka belum mampu menggunakan keterampilan matematikannya untuk menyelesaikan soal literasi matematika yang paling mudah. Sedangkan $20 \%$ siswa berada pada level 1 yang berarti siswa sudah mampu menjawab pertanyaan yang konteksnya umum dan dikenal semua informasi yang relevan terssedia dengan pertanyaan yang jelas, mereka bisa mengidentifikasi informasi dan menyelesaikan prosedur rutin menurut instruksi yang eksplisit dan dapat melakukan tindakan sesuai dengan stimulus yang diberikan. Sesuai dengan hasil penelitian (Anggrieni \& Putri, 2018) kemampuan literasi 


\section{Histogram: Jurnal Pendidikan Matematika, 4 (1), 2020 - 134 Anis Munfarikhatin ${ }^{1 *}$, Irmawaty Natsir ${ }^{2}$}

matematika aspek komunikasi mendominasi level capaian literasi matematika siswa,(Marina \& Yusmin, 2016) tingkat literasi matematika siswa yang rendah dapat dilihat dari cara penyelesaian masalah dengan perencanaan penyelesaian, tidak sekedar menggunakan rumus.

\section{B. Pembahasan}

Gambar 1 menunjukkan proses siswa dalam menyelesaikan tes literasi matematika konten space and shape. Proses analisis data menggunakan lembar jawab tes kemampuan literasi matematika pada konten space and shape materi pythagoras. Terdapat 7 indikator proses dalam kemampuan literasi yang dianalisis diantaranya: (1) komunikasi, (2) mathematising, (3) representation, (4) reasoning, (5) argument, (6) devising strategies and solving problems, (7) using symbolic, formal, technical language, operation, and mathematics tools.

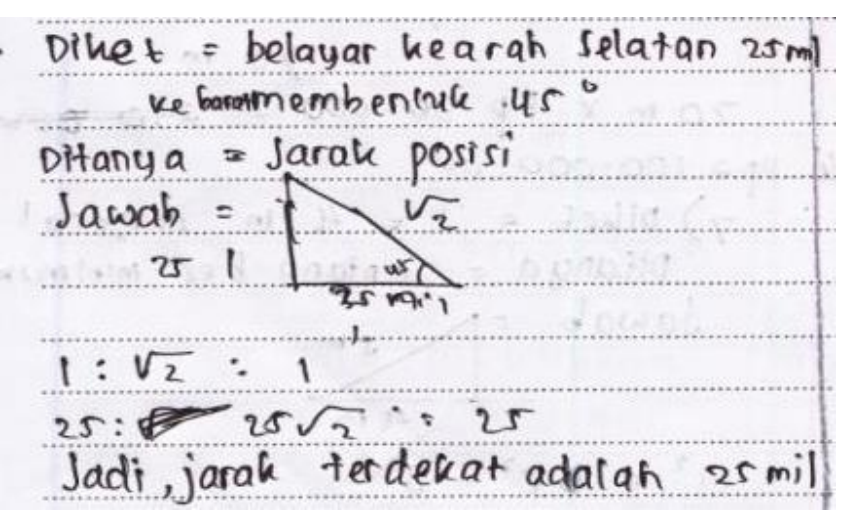

Gambar 1. Hasil Pekerjaan Siswa PR

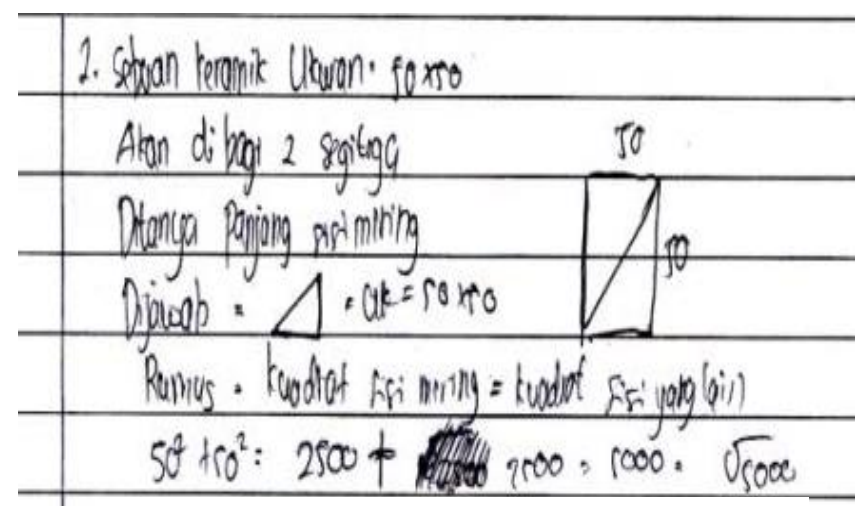

Gambar 2. Hasil Pekerjaan Siswa FBAS

Pada gambar 1 terlihat bahwa PR dalam mengolah informasi dari soal belum sepenuhnya baik. Sehingga pada level komunikasi PR memenuhi kriteria cukup. Pada tahap selanjutnya yaitu merumuskan masalah secara matematika. Pada tahap ini dapat 


\section{Histogram: Jurnal Pendidikan Matematika, 4 (1), 2020 - 135 Anis Munfarikhatin ${ }^{1 *}$, Irmawaty Natsir ${ }^{2}$}

dilihat kemampuan PR dalam menentukan perbandingan sudut- sudut istimewa segitiga siku- siku sama kaki. Pada tahap mathematising ini PR termasuk pada kategori baik. Dalam menentukan pemecahan masalah PR menggunakan perbandingan dalam menentukan jarak terdekat yaitu diperoleh hasil 25 mil. Pada tahap ini kemampuan PR dalam proses devising strategies and solving problem sudah tergolong baik. Terlihat pada tahap ini PR telah mampu menyimpulkan proses perhitungan. Sehingga dapat dikatakan kemampuan literasi PR sudah baik meskipun tidak terlalu besar.

Serupa dengan PR, siswa FBAS juga memiliki kesulitan yang sama saat menyelesaikan soal nomor 2. Ia kurang cermat dalam memahami soal, sehingga jawaban tidak sesuai dengan yang diharapkan. Soal nomor 2 merupakan soal dengan kategori mudah. Namun pada kenyataannya FBAS belum mampu menjawab dengan tepat.

Dari hasil wawancara dengan FBAS memang siswa tersebut menyadari bahwa ia kurang cermat dalam mengerjakan soal, khususnya nomor 2. Dari pekerjaan FBAS tersebut dapat dilihat bahwa dalam proses mengkomuikasikan ia sudah mampu. Ini terbukti FBAS dapat menuliskan dengan benar mengenai apa yang diketahui dalam soal. Namun pada aspek mathematising FBAS mulai ragu- ragu. Yang harus ia temukan adalah menentukan ukuran keramik yang telah dipotong. Sebenarnya, langkah yang FBAS lakukan sudah mendekati kebenaran yang terbukti bahwa siswa tersebut telah mampu menentukan panjang sisi miring dari segiempat yang telah dipotong. Akibatnya dalam proses devising strategies and solving problems menjadi tidak benar.

Masing- masing indikator kemampuan literasi matematika dijabarkan dalam lima skor yaitu: (1) skor 1 : jika indikator tidak ditemukan sama sekali pada subyek penelitian, (2) skor 2: jika indikator jarang ditemukan pada subyek penelitian, (3) skor 3: jika indikator kadang ditemukan pada subyek penelitian, (4) skor 4: jika indikator sering ditemukan pada subyek penelitian, (5) skor 5: jika indikator selalu ditemukan pada subyek penelitian.

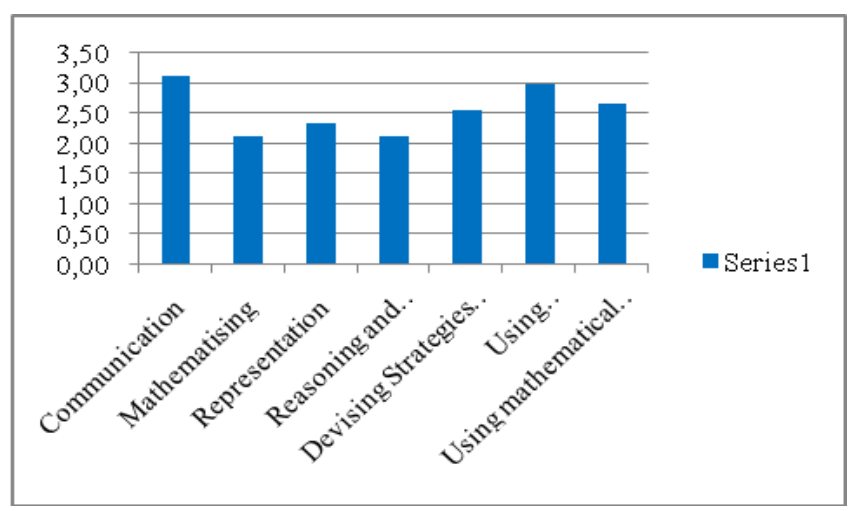

Gambar 3. Grafik indikator rata-rata skor literasi ISSN: 2549-6700 (print), ISSN 2549-6719 (online) 


\section{Histogram: Jurnal Pendidikan Matematika, 4 (1), 2020 - 136 Anis Munfarikhatin ${ }^{1 *}$, Irmawaty Natsir ${ }^{2}$}

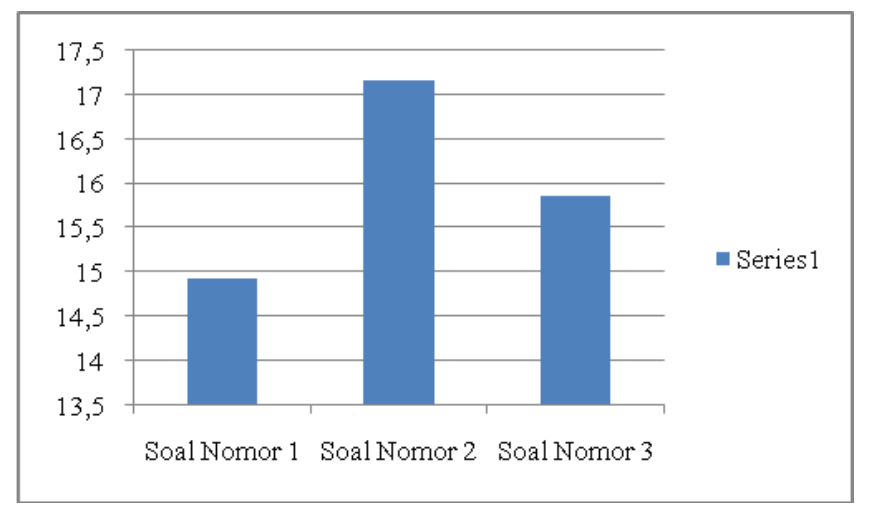

Gambar 4. Grafik skor rata-rata per butir soal

Analisis hasil penelitian tentang kemampuan literasi siswa kelas VIII G berdasarkan hasil observasi dan dokumentasi lembar jawab tes kemampuan literasi pada konten space and shape. (1) Skor rata- rata untuk kemampuan communication adalah 3,13 yang berarti bahwa para siswa cukup komunikatif dalam menjawab, mengajukan pertanyaan, dan presentasi di kelas, (2) skor rata- rata kemampuan mathematising 2,13 yang berarti bahwa siswa kurang mampu dalam mengidentifikasi variabel matematika yang bertujuan untuk mempermudah dalam pemecahan masalah matematika, (3) skor rata- rata kemampuan representation adalah 2,33 yang berarti bahwa siswa kurang mampu membuat representasi matematika dari informasi yang diperoleh ke dalam dunia nyata, (4) skor ratarata kemampuan reasoning adalah 2,13 yang berarti bahwa siswa belum mampu menjelaskan dan mempertahankan atau memberikan pembenaran untuk proses dan prosedur yang digunakan untuk menentukan hasil matematis, (5) skor rata- rata kemampuan devising strategies for solving problem adalah 2,56 yang berarti siswa belum mampu menyusun rencana atau strategi dalam membingkai ulang masalah matematis yang dikontekstualisasiakan, (6) skor rata- rata kemampuan using symbolic, formal and technical language and operation adalah 3,00 yang berarti bahwa siswa cukup dalam menggunakan variabel yang tepat, simbol, diagram dan model standar untuk mewakili masalah dunia nyata, (7) skor rata- rata untuk using mathematical tools adalah 2,66 yang berarti bahwa siswa belum mampu menggunakan alat-alat matematika untuk mengenali struktur matematika atau untuk menggambarkan hubungan matematis. Alat matematika dalam hal ini diantaranya adalah internet, kalkulator, dan media pembelajaran lain yang mendukung proses pembelajaran. (Munfarikhatin, 2019) Kemampuan literasi dapat 


\section{Histogram: Jurnal Pendidikan Matematika, 4 (1), 2020 - 137 Anis Munfarikhatin ${ }^{1 *}$, Irmawaty Natsir ${ }^{2}$}

ditingkatkan dengan memberikan permasalahan yang berbasis literasi pada pembelajaran sehari-hari.

\section{KESIMPULAN DAN SARAN}

\section{A. Kesimpulan}

Berdasarkan hasil penelitian dan pembahasan analisis kemampuan literasi matematika pada konten space and shape, dapat disimpulkan sebagai berikut. Sebanyak $20 \%$ kemampuan proses literasi matematika pada aspek communication, using symbolic, formal and technical language and operation berada pada level 1 yang berarti bahwa siswa sudah mampu menjawab pertanyaan yang konteksnya umum dan dikenal serta semua informasi yang relevan tersedia denga pertanyaan yang jelas dan sudah mampu mengidentifikasi informasi dan menyelesaikan prosedur rutin menurut instruksi yang eksplisit serta dapat melakukan tindakan sesuai dengan stimulus yang diberikan. Sebanyak $80 \%$ siswa menempati level di bawah 1 pada komponen aspek mathematising, representation, reasoning and argument, devising strategies and solving problem, using mathematics tools. Hal ini berarti siswa belum mampu menggunakan operasi matematika dengan benar, serta belum mampu menggunakan keterampilan matematikannya untuk menyelesaikan soal matematika yang paling mudah.

\section{B. Saran}

Penelitian ini dapat dijadikan bahan rujukan oleh pengajar khususnya guru di sekolah menengah untuk mengukur sejauh mana kemampuan literasi siswa dan dapat dikembangkan penelitian lebih lanjut dengan mengembangkan soal- soal literasi matematika beorientasi PISA maupun dengan menerapkan model dan metode dengan tujuan meningkatkan literasi siswa.

\section{DAFTAR PUSTAKA}

Adolphus, T. (2011). Problems of Teaching and Learning of Geometry in Secondary School in Rivers State, Nigeria. IJES, 1(2), 143-152.

Afriyanti, I., Sri, T., \& Asih, N. (2018). Mathematical Literacy Skills Reviewed From Mathematical Resilience in The Learning of Discovery Learning Assisted by Schoology, Unnes Journal of Mathematics Education Research, 7(23), 71-78.

Anggrieni, N., \& Putri, R, I, I. (2018). Analisis Kemampuan Literasi Matematika Siswa Kelompok Kecil dalam Menyelesaikan Soal Matematika Tipe PISA, In Prosiding Sendikmad 6, Universitas Ahmad Dahlan, 6(1), 472-481.

Aydogdu, M. Z. (2014). A Research on Geometry Problem Solving Strategies Used by Elementary Mathematics Teacher Candidates. Journal of Educational And 


\section{Histogram: Jurnal Pendidikan Matematika, 4 (1), 2020 - 138 Anis Munfarikhatin ${ }^{1 *}$, Irmawaty Natsir ${ }^{2}$}

Instructional Studies In The World, 4(1), 53 - 62.

Hayat, B. and Y. (2010). International Benchmark for Quality of Education. Jakarta: Bumi Aksara.

Haarh, J., Nielsen, T., Hansen, E, \& Jakobsen, S. (2005). Explaining Student Performance: Evidence from the International PISA, TIMSS and PIRLS Surveys. Danish Technological Institute.

Munfarikhatin, A. (2019). Keefektivan Model PBL Strategi Murder terhadap Kemampuan Literasi Matematika Siswa. Musamus Jurnal of Mathematics Education, 2(1), 32 -42.

OECD. (2010). PISA 2009 Results: Executive Summary. Paris: OECD Publishing

OECD. (2013). PISA 2013 Financial Literacy Assessment Framework. Paris: OECD Publishing

OECD. (2018). PISA 2015 Result in Focus. Paris: OECD Publishing

Saragih, G, B, A., Palobo, M., \& Sianturi, M. (2019). Analisis Faktor- Faktor yang Mempengaruhi Siswa Madrasah Aliyah Al Munawwaroh Merauke Tahun Akademik 2017/2018. Musamus Journal of Mathemaics Education, 1(2), 62-73.

Setiawan, H., Dafik, dan Lestari, N., Diah Sri. (2014). Soal Matematika Dalam PISA Kaitannya Dengan Literasi Matematika Dan Keterampilan Berpikir Tingkat Tinggi. In Prosiding Seminar Nasional Matematika, 1(1), 244 - 251

Xiaonan, X. (2018). A Research on the Development of Innovative Mathematics Teaching in Higher Education. Int. Conf. Manag. Educ. Soc. Sci., 176, pp 777-781.

Marina., Yusmin, E., \& T, A. Y. (2016). Proses Literasi Matematis Dikaji dari Content Space and Shape Dalam Materi Geometri di SMA. Jurnal Pendidikan dan Pembelajaran Khatulistiwa, 5(11), 1-11. 